\author{
JÓZEF KOREDCZUK \\ ORCID: 0000-0002-3471-568X \\ Uniwersytet Wrocławski \\ jozef.koredczuk@uwr.edu.pl
}

\title{
Sędziowie śledczy do spraw wyjątkowego znaczenia w II Rzeczypospolitej
}

Jedną z instytucji procesowych wzbudzających liczne kontrowersje w prawie, orzecznictwie, literaturze i doktrynie II Rzeczypospolitej była instytucja sędziów śledczych. Doczekała się ona wielu opracowań, w tym także historycznoprawnych $^{1}$, odmiennie niż instytucja sędziów śledczych do spraw wyjątkowego znaczenia, która doczekała się jedynie krótkich wzmianek ${ }^{2}$.

Instytucja sędziów śledczych do spraw wyjątkowego znaczenia różniła się od zwykłych sędziów śledczych. O ile bowiem instytucja sędziów śledczych we wszystkich krajach (w tym także w Polsce), w których była znana, miała rodowód francuski - wywodziła się z napoleońskiego Code d' instruction criminelle z 1808 roku, o tyle instytucja sędziów śledczych do spraw wyjątkowych miała rodowód rosyjski - wywodziła się z ustawy postępowania karnego z 1864 roku, a konkretnie instytucji sędziów śledczych do spraw szczególnej wagi ${ }^{3}$. $Z$ tego też powodu, niekiedy nawet po 1927 roku, nadal określano sędziów śledczych do spraw wyjątkowego znaczenia jako sędziów śledczych do spraw szczególnej wagi.

Ustawodawstwo byłego zaboru rosyjskiego znało delegowanie do przeprowadzenia śledztwa wstępnego w wypadkach „szczególnej wagi”, mianowicie zamiast

1 Por. np. W. Nestorowicz, Stanowisko sędziego śledczego u nas i na zachodzie, „Głos Sądownictwa" 4, 1932, nr 3-4; M. Materniak-Pawłowska, Instytucja sędziego śledczego w okresie międzywojennym, „Czasopismo Prawno-Historyczne” 65, 2013, z. 1; K. Eichstaedt, Instytucja sędziego śledczego w okresie międzywojennym, „Studia z Dziejów Państwa i Prawa Polskiego” 17, 2014.

2 Por. J. Koredczuk, Ewolucja modelu postępowania przygotowawczego, [w:] System Prawa Karnego Procesowego, red. P. Hofmański, t. 10. Postępowanie przygotowawcze, red. R.A. Stefański, Warszawa 2016, s. 95-96.

3 Okólnik Nr. 1422/I. U/28 dotyczący prawa o ustroju sądów powszechnych, Dziennik Urzędowy Ministerstwa Sprawiedliwości 1928, nr 19, s. 366. 
właściwego sędziego śledczego sąd apelacyjny miał prawo delegować innego sędziego - sędziego sądu okręgowego, a nawet apelacyjnego (art. 288 cz. 2 u.p.k. ${ }^{4}$ ). Czteroletnia praktyka z instytucją sędziów delegowanych wykazała jednak, że głównie z powodu niewielkiej liczby etatów sądowych — zarówno okręgowych, jak i apelacyjnych - sędziowie delegowani do prowadzenia powierzonego im śledztwa nie byli zwolnieni od swojej zasadniczej pracy i wobec tego ciągle byli odrywani od udziału w posiedzeniach sądowych. Wskutek tego zapatrywali się oni na obowiązek prowadzenia śledztw jako na pracę uboczną, której nie poświęcali się wystarczająco, a tym bardziej wyłącznie. Tymczasem życie pokazało, że czasami pojawiała się potrzeba istnienia instytucji sędziów śledczych do spraw wyjątkowego znaczenia. Były to na przykład sprawy karne, które wymagały całkowitego poświęcenia im czasu oraz szczególnych umiejętności (na przykład znajomości prawa międzydzielnicowego lub programów stowarzyszeń wywrotowych ${ }^{5}$ ), których właściwy sędzia śledczy często nie miał. Z tych względów, uważając istnienie instytucji sędziów śledczych do spraw wyjątkowego znaczenia za konieczność państwową, Ministerstwo Sprawiedliwości 16 listopada 1925 roku wniosło do Sejmu projekt ustawy o sędziach śledczych do spraw wyjątkowego znaczenia (druk nr 2194) ${ }^{6}$. Po ponad dwu i pół roku projekt doczekał się rozpatrzenia, ale został przyjęty nie w formie ustawy Sejmu, jak początkowo wnoszono, lecz rozporządzenia Prezydenta Rzeczypospolitej. Biorąc pod uwagę zmiany, jakie zaszły w Polsce między listopadem 1924 roku a lipcem 1927 roku, można stwierdzić, że być może nie było to przypadkowe i projektowanej instytucji nadawało zupełnie inne znaczenie - nie tylko formalnoprawne, lecz przede wszystkim polityczne. Ostatecznie status sędziów śledczych do spraw wyjątkowego znaczenia uregulowało rozporządzenie Prezydenta Rzeczypospolitej z dnia 15 lipca 1927 roku (Dz.U. RP Nr 69, poz. 611), które weszło w życie dnia 10 sierpnia 1927 roku.

O wiele szerzej walory instytucji sędziów śledczych do spraw wyjątkowego znaczenia przedstawił niespełna rok później — przy okazji wejścia w życie Prawa o ustroju sądów powszechnych na zjeździe prezesów sądów apelacyjnych

4 Taką możliwość wprowadzono do rosyjskiej ustawy postępowania karnego na mocy art. 27 ustawy z dnia 15 lutego 1921 roku w przedmiocie zmian w ustawodawstwie karnem, obowiązującem w b. zaborze rosyjskim (Dz.U. RP Nr 30, poz. 169).

5 Odwołując się do tego kryterium, Rada Adwokacka w Lublinie w 1954 roku odmówiła wpisania na listę adwokatów Zdzisławowi Papierkowskiemu (profesorowi KUL), powołując się na fakt, że w okresie międzywojennym był sędzią śledczym do spraw wyjątkowego znaczenia, „tj. spraw o przynależność do KPP i innych organizacji lewicowych" — P. Sandecki, Adwokat profesor Zdzisław Papierkowski (1903-1980) - w 110. rocznicę urodzin, „Palestra” 58, 2013, nr 3-4, s. 259. Z. Papierkowski w rzeczywistości był sędzią śledczym, ale sądu okręgowego w Lublinie, a nie do spraw wyjątkowego znaczenia - Kalendarz Informator Sądowy na rok 1934, oprac. J. Kirkiczenko, M. Kraczkiewicz, K. Rudzisz, Warszawa [b.r.], s. 86.

6 Sędziowie śledczy do spraw wyjątkowego znaczenia, „Palestra” 2, 1925, nr 12, s. 1154. Projekt tej ustawy por. https://bs.sejm.gov.pl/exlibris/aleph/a22_1/apache_media/3JY2NQTTI2ISIHT L9A9JNBM9EIDRH7.pdf (dostęp: 10 kwietnia 2020). 
i prokuratorów apelacyjnych w dniach 28-30 czerwca 1928 roku w Ministerstwie Sprawiedliwości — prokurator Sądu Najwyższego Władysław Kuczyński. Jego zdaniem korzyści wynikające z tej instytucji były oczywiste, umożliwiała ona bowiem łączenie w jednych rękach spraw z różnych okręgów sądowych, choć nie było ku temu przesłanek procesowych, a tylko przemawiały za tym względy faktyczne, na przykład: 1. w wypadkach rozgałęzionych na większych obszarach knowań antypaństwowych, choć nie wykazano wspólnictwa oskarżonych, albo w wypadkach, gdy materiał zebrany w poszczególnych sprawach nie był wystarczający do oskarżenia bezpośrednio działających, lecz wystarczał tylko do oskarżenia o drobne przestępstwa (sprawy), pomiędzy którymi zachodząca łączność dawała podstawę do ujawnienia zbrodniczej akcji państwowej u źródła, w centrali, i do oskarżenia jej członków; 2. w niektórych sprawach (na przykład zawiłych bankowo, o oszustwa, szpiegostwo) wymagających — celem należytego ich ujęcia — znajomości specjalnej literatury, urządzeń i rozległych informacji z wywiadu, które miał sędzia do spraw wyjątkowego znaczenia, a które inny sędzia musiałby dopiero sobie przyswajać przez studia wstępne z uszczerbkiem dla toku śledztwa wymagającego fachowego kierunku i pospiechu; 3. w sprawach, które miały takie zabarwienie lokalne, że nie przesądzając jeszcze właściwości sądu wyrokującego w trybie delegacji (art. 38 k.p.k.), wskazane było poruczenie zbadania sprawy sędziemu hierarchicznie wyższemu i niezwiązanemu stosunkami lokalnymi (art. 258 § 3 i 4 k.p.k.); 4. administracja sądowa dzięki tej instytucji miała możność zatrzymania na stanowiskach sędziów śledczych jednostek szczególnie uzdolnionych na te stanowiska ${ }^{7}$.

Status sędziów śledczych do spraw wyjątkowego znaczenia określało nie tylko rozporządzenie z 1927 roku, lecz także przepisy rozporządzenia Prezydenta Rzeczypospolitej z dnia 6 lutego 1928 roku Prawo o ustroju sądów powszechnych (Dz.U. RP Nr 12, poz. 93). Zgodnie z art. $280 \S 1$ i 2 tego rozporządzenia osoby, które dotychczas zajmowały stanowisko sędziego śledczego do spraw wyjątkowego znaczenia na podstawie rozporządzenia z 1927 roku, stały się sędziami apelacyjnymi śledczymi do spraw wyjątkowego znaczenia. Zdaniem Adolfa Czerwińskiego postanowienia tego rozporządzenia odnośnie do sędziów śledczych do spraw wyjątkowego znaczenia budziły wątpliwości, ponieważ obniżały powagę sędziów śledczych okręgowych oraz stwarzały mylne wrażenie, że sędziowie apelacyjni śledczy są jakby wyższym organem śledczym w porównaniu do sędziów śledczych okręgowych, którym w rzeczywistości nie były ${ }^{8}$. Potwierdzeniem jest chociażby to, że zgodnie z art. 7 rozporządzenia o sędziach śledczych decyzje

${ }^{7}$ Okólnik Nr. 1422/I. U/28, s. 366. Okólnik wydany na tym zjeździe stanowił oficjalny komentarz Ministerstwa Sprawiedliwości do Prawa o ustroju sądów powszechnych.

8 A. Czerwiński, Ustrój sądów powszechnych wedle rozporządzenia Prezydenta Rzeczypospolitej z dnia 6 lutego 1928 r. Dz. Ust. Nr. 12, poz. 93, Lwów 1928, s. 17. Warto dodać, że Adolf Czerwiński był prezesem Sądu Apelacyjnego we Lwowie do czerwca 1929 roku. 
(postanowienia) sędziego śledczego do spraw wyjątkowego znaczenia podlegały zaskarżeniu do sądu okręgowego w siedzibie tegoż sędziego, a nie do sądu apelacyjnego.

Zakres działania sędziów śledczych do spraw wyjątkowego znaczenia pokrywał się z właściwością apelacji. Pod względem stanowiska służbowego, a w szczególności nadzoru, odpowiedzialności dyscyplinarnej i uposażenia, pozycja tych sędziów była zrównana ze stanowiskiem sędziów sądu apelacyjnego. Celem powołania sędziów śledczych do spraw wyjątkowego znaczenia było skupienie w rękach jednego doświadczonego i odsuniętego od lokalnych stosunków sędziego śledczego zakresu poważnych przestępstw popełnionych w kilku okręgach. Wspomniany nadzór nad nimi sprawował kierownik nadzoru prokuratorskiego w Ministerstwie Sprawiedliwości, któremu zobowiązani byli oni składać kwartalne i roczne wykazy czynności podjętych w prowadzonych przez siebie sprawach. Ich głównym zadaniem było prowadzenie śledztwa. Byli wprowadzani do postępowania na podstawie uchwały Sądu Najwyższego lub uchwały sądu apelacyjnego 9 . Sędziów śledczych do spraw wyjątkowego znaczenia nie można było powoływać do składów sądzących, a jeżeli już, to tylko dla uzupełnienia składu w nagłych wypadkach i nie ponad miarę zakreśloną przez Ministra Sprawiedliwości ${ }^{10}$. Potwierdzenie zakresu tych kompetencji sędziów śledczych do spraw wyjątkowego znaczenia znajdujemy w uzasadnieniu wyroku Najwyższego Trybunału Administracyjnego z dnia 29 maja 1934 roku (1. rej. 2986/31 i 4745/31), w którym stwierdził on, że z brzmienia art. $5 \S 1$ i 2 prawa o ustroju sądów powszechnych wynika, że sędzia śledczy do spraw wyjątkowego znaczenia wyznaczony jest do sprawowania specjalnych funkcji sędziowskich określonych w kodeksie postępowania karnego $^{11}$. Trochę szerszy zakres kompetencji sędziów śledczych do spraw wyjątkowego znaczenia przewidywał projekt ustawy z 1924 roku ich dotyczącej, zgodnie z którym na mocy zarządzenia ministra mogli oni również pomagać prezesowi sądu apelacyjnego swej siedziby w czynnościach administracyjnych i nadzorczych, a przygotowawczo także w innych ${ }^{12}$.

Do instytucji sędziów śledczych do spraw wyjątkowego znaczenia odnosi się także kodeks postępowania karnego z 1928 roku $^{13}$. Czyni to w art. $258 \S 3$

9 A. Węklar, Instytucja sędziego śledczego do spraw postępowania przygotowawczego na tle uwarunkowań polskiego systemu prawnego - rozważania de lege ferenda, Warszawa 2019, s. 34.

10 S. Śliwiński, Polski proces karny przed sadem powszechnym. Zasady ogólne, Warszawa 1948, s. 280. Kompetencje Ministra Sprawiedliwości co do wykorzystania sędziów śledczych do spraw wyjątkowego znaczenia w nagłych przypadkach zostały zniesione na podstawie art. 3 pkt 15 dekretu Prezydenta Rzeczypospolitej z dnia 21 października 1944 roku o zmianie niektórych przepisów prawa o ustroju sądów powszechnych (Dz.U. RP na Uchodźstwie Nr 12, cz. I, poz. 23).

11 Zbiór Wyroków Najwyższego Trybunału Administracyjnego 12, 1934, red. K. Bernaczyk, W. Borkowski, A. Dubieński, Z. Smolka, Warszawa 1935, poz. nr 770A, s. 172.

12 Sędziowie śledczy do spraw..., s. 1155.

13 Rozporządzenie Prezydenta Rzeczypospolitej z dnia 19 marca 1928 roku Kodeks postępowania karnego (Dz.U. RP Nr 33, poz. 313). 
i 4, przepisach, które do projektu kodeksu dodane zostały z inicjatywy Ministra Sprawiedliwości. Zgodnie z art. 258 § 3 k.p.k. z 1928 roku sędzia śledczy do spraw wyjątkowego znaczenia mógł także — oprócz zwykłego sędziego śledczego prowadzić śledztwo. Był on w tym wypadku wyznaczany przez sąd apelacyjny na wniosek prokuratora apelacyjnego. Natomiast na wniosek Naczelnego Prokuratora (czyli Ministra Sprawiedliwości) Sąd Najwyższy mógł do przeprowadzenia danej sprawy wyznaczyć jednego spośród sędziów śledczych do spraw wyjątkowego znaczenia, czynnych w sądach apelacyjnych (art. $258 \S 4$ k.p.k.) ${ }^{14}$. Sytuacja przewidziana w art. $258 \S 3$ k.p.k. — zlecenie prowadzenia śledztwa sędziemu śledczemu do spraw wyjątkowego znaczenia przez sąd apelacyjny - miała zastosowanie, gdy śledztwo w danej sprawie miało być prowadzone w ramach okręgu jednego sądu apelacyjnego, przy którym tenże sędzia śledczy został ustanowiony. Natomiast sytuacja przewidziana w art. $258 \S 4$ k.p.k. - wyznaczenie do prowadzenia sprawy sędziego śledczego do spraw wyjątkowego znaczenia przez Sąd Najwyższy - miała zastosowanie, gdy sprawa ta miała być prowadzona w ramach okręgów różnych sądów apelacyjnych bądź też gdy była prowadzona w ramach okręgu jednego sądu apelacyjnego, ale Sąd Najwyższy postanowił powierzyć jej prowadzenie nie sędziemu śledczemu ustanowionemu przy tym sądzie apelacyjnym, lecz jednemu spośród sędziów śledczych do spraw wyjątkowego znaczenia czynnych przy wszystkich sądach apelacyjnych w Polsce ${ }^{15}$. Artykuł $258 \S 4$ k.p.k. stwarzał możliwość zmiany właściwości sądu ustalonej zgodnie z art. 24 lub 25 k.p.k. ${ }^{16}$ Warto przy okazji zwrócić uwagę, że w $§ 3$ art. 258 k.p.k. wspomina się o „prowadzeniu śledztwa”, a w $\S 4$ tego artykułu o „przeprowadzeniu danej sprawy".

W przypadku prowadzenia sprawy przez sędziego śledczego do spraw wyjątkowego znaczenia wyznaczonego na wniosek Ministra Sprawiedliwości jako Naczelnego Prokuratora — zgodnie z art. 8 rozporządzenia z 1927 roku — uprawnienia służące prokuraturze wykonywał delegowany przez Ministra Sprawiedliwości przedstawiciel prokuratury. Na wniosek tego przedstawiciela prokuratury sędzia śledczy do spraw wyjątkowych mógł przekazać sprawę sędziemu śledczemu właściwemu według zasad ogólnych. Jeśli jednak by to uczynił, to wtedy Minister Sprawiedliwości nie mógł ponownie wystąpić z wnioskiem o powierzenie prowadzenia tej sprawy sędziemu śledczemu do spraw wyjątkowego znaczenia. Analogiczne zasady obowiązywały, gdy śledztwo prowadził sędzia śledczy do spraw wyjątkowego znaczenia wyznaczony na wniosek prokuratora apelacyjnego, $z$ tą jednakże różnicą, że uprawnienia służące prokuraturze wykonywał prokurator apelacyjny osobiście lub przez delegowanego zastępcę. Sędzia śledczy do spraw

14 K. Eichstaedt, op. cit., s. 185; A. Węklar, op. cit.

15 A. Mogilnicki, Śledztwo i akt oskarżenia wedtug k. p. k. i projektu, „Gazeta Sądowa Warszawska" 58, 1930, nr 2, s. 20.

16 J. Gumiński, Zakres działania Sądu Najwyższego w świetle nowych przepisów, „Głos Sądownictwa" 1,1929 , nr 1, s. 3. 
wyjątkowego znaczenia o rozpoczęciu przez siebie śledztwa zawiadamiał właściwego sędziego śledczego (powiatowego) lub sędziego delegowanego. Sędziowie ci po otrzymaniu tego zawiadomienia obowiązani byli przesłać sędziemu śledczemu do spraw wyjątkowego znaczenia akta swych dotychczasowych czynności w sprawie i od tej chwili w przedmiotowej sprawie mogli przedsiębrać bez jego żądania tylko czynności niecierpiące zwłoki (art. 5 rozporządzenia z 1927 roku).

Oprócz art. 258 § 3 i 4 — spośród przepisów rozdziału trzeciego księgi szóstej kodeksu postępowania karnego poświęconych śledztwu (czyli art. 258-276) istotne znaczenie dla sędziów śledczych do spraw wyjątkowego znaczenia miał także zapewne art. 270 k.p.k., stanowiący, że jeżeli okoliczności sprawy tego wymagają, sędzia śledczy może wzywać do siebie osoby przebywające w innym okręgu oraz dokonywać czynności i poza swoim okręgiem ${ }^{17}$.

Wpływ na zmianę statusu sędziów śledczych do spraw wyjątkowego znaczenia miały regulacje nie tylko bezpośrednio ich dotyczące, ale także dotyczące zwykłych sędziów śledczych. Sędziów do spraw wyjątkowego znaczenia można bowiem uznać za ich odmianę. Odnośnie do sędziów śledczych istotne zmiany przyniosły dwie nowelizacje kodeksu postępowania karnego z 1928 roku dokonane w 1932 roku, na mocy których praktycznie zatarła się różnica między śledztwem a dochodzeniem oraz znacznie poszerzył zakres czynności dokonywanych przez sędziów śledczych ${ }^{18}$. Kluczowe znaczenie w kodeksie postępowania karnego miały także stosunki pomiędzy sędzią śledczym a prokuratorem, które w polskim kodeksie oparto na modelu rosyjskim, czyli takim, w którym sędzia śledczy był zależny od prokuratora ${ }^{19}$. Miało to szczególnie istotne znaczenie w odniesieniu do sędziów śledczych do spraw wyjątkowego znaczenia, do których odpowiednie zastosowanie miały przepisy kodeksu o sędziach śledczych.

Istotniejsze zmiany w rozporządzeniu o sędziach śledczych do spraw wyjątkowego znaczenia niż związane $\mathrm{z}$ wydaniem kodeksu postępowania karnego z 1928 roku przyniosły postanowienia rozporządzenia Prezydenta Rzeczypospolitej z dnia 19 marca 1928 roku. Przepisy wprowadzające kodeks postępowania karnego (Dz.U. RP Nr 33, poz. 314). Zgodnie bowiem z art. $1 \S 2$ pkt 13 tego

17 Analogiczny przepis odnośnie do sędziów śledczych do spraw wyjątkowego znaczenia zawierało rozporządzenie z 1927 roku, konkretnie art. 6, zgodnie z którym sędzia śledczy do spraw wyjątkowego znaczenia przeprowadzał śledztwo (dochodzenie) na zasadach obowiązujących właściwego sędziego śledczego; był władny przedsiębrać poszczególne czynności na całym obszarze państwa w trybie ustawy postępowania karnego, według której prowadził całość śledztwa (dochodzenia); mógł także żądać od właściwych sędziów śledczych (sądów) wykonania poszczególnych czynności lub zadań.

18 J. Koredczuk, Wplyw nurtu socjologicznego na ksztalt polskiego prawa karnego procesowego w okresie międzywojennym (Les classiques modernes), Wrocław 2007, s. 104.

19 J. Koredczuk, Wpływ francuskiego kodeksu postępowania karnego z 1808 roku na polski kodeks postępowania karnego z 1928 roku, [w:] Ze studiów nad tradycją prawa, red. E. Kozerska, P. Sadowski, A. Szymański, Warszawa 2012, s. 93. 
rozporządzenia po dniu 1 lipca 1929 roku w mocy pozostały tylko art. 5, 7 i 8 rozporządzenia o sędziach śledczych do spraw wyjątkowego znaczenia, pozostałe utraciły moc obowiązującą. Zmiany te zostały przeoczone przez badaczy piszących o sędziach śledczych do spraw wyjątkowego znaczenia. Nie ujmuje ich nawet Internetowy System Aktów Prawnych. W zakresie uchylonych przepisów rozporządzenia o sędziach śledczych do spraw wyjątkowego znaczenia odpowiednie zastosowanie od tej pory miały przepisy rozporządzenia - Prawo o ustroju sądów powszechnych oraz kodeksu postępowania karnego.

Jednemu z sędziów śledczych do spraw wyjątkowego znaczenia, zgodnie z art. 21 ust. 3 ustawy z dnia 14 lipca 1936 roku o Trybunale Stanu (Dz.U. RP Nr 56, poz. 403), przewodniczący Trybunału w razie potrzeby mógł zlecić przeprowadzenie śledztwa lub przedsięwzięcie poszczególnych czynności śledczych w sprawie rozpatrywanej przez Trybunał. Była to jedynie możliwość hipotetyczna, albowiem pod rządami ustawy z 1936 roku Trybunał nie rozpatrywał żadnej sprawy. Jedyną sprawą rozpatrywaną przez Trybunał Stanu w okresie międzywojennym była sprawa Gabriela Czechowicza, ministra skarbu w rządzie Józefa Piłsudskiego, jednakże w marcu 1929 roku, kiedy miała ona miejsce, mimo że instytucja sędziów śledczych do spraw wyjątkowego znaczenia była już powołana do życia, to jednak ówcześnie obowiązujące w tym zakresie przepisy, to jest ustawa z dnia 23 kwietnia 1923 roku o Trybunale Stanu (Dz.U. RP Nr 59, poz. 415) oraz rozporządzenia Prezydenta Rzeczypospolitej z dnia 22 kwietnia 1927 roku o postępowaniu sądowym w razie naruszenia postanowień art. 22 Konstytucji (Dz.U. RP. Nr 41, poz. 368) przewidywały, że dochodzenie w sprawie osób postawionych przed Trybunałem Stanu przeprowadza sędzia Sądu Najwyższego wyznaczony przez Pierwszego Prezesa Sądu Najwyższego (czyli jednocześnie Przewodniczącego Trybunału Stanu).

O wiele częściej natomiast w praktyce podstawą powierzenia śledztw sędziom śledczym do spraw wyjątkowego znaczenia były postanowienia rozporządzenia Prezydenta Rzeczypospolitej z dnia 24 października 1934 roku o niektórych przestępstwach przeciwko bezpieczeństwu Państwa (Dz.U. RP Nr 94, poz. 851). Zgodnie z art. 29 ust. 1 tego rozporządzenia na wniosek prokuratora do prowadzenia śledztwa w przypadkach przewidzianych tym rozporządzeniem prezes sądu apelacyjnego mógł wyznaczyć jednego spośród sędziów śledczych czynnych w okręgu danego sądu apelacyjnego bądź spośród sędziów śledczych do spraw wyjątkowego znaczenia, czynnych w danym sądzie apelacyjnym, co często się zdarzało.

Liczba i siedziby sędziów śledczych do spraw wyjątkowego znaczenia miały być określone przez Ministra Sprawiedliwości w granicach budżetu i dostosowane do: 1. rzeczywistych potrzeb specjalizacji w zakresie prawa trzech dzielnic; 2. rodzaju spraw (agitacji politycznej, zamachów, nadużyć urzędowych itp.); 3. znajomości stosunków na poszczególnych obszarach państwa ${ }^{20}$.

${ }^{20}$ Uzasadnienie do projektu ustawy o sędziach śledczych do spraw wyjątkowego znaczenia. 
Już półtora miesiąca po wejściu w życie rozporządzenia o sędziach śledczych do spraw wyjątkowego znaczenia minister sprawiedliwości Aleksander Meysztowicz wydał dnia 27 września 1927 roku rozporządzenie w sprawie ustanowienia w mieście stołecznym Warszawie sędziów śledczych do spraw wyjątkowego znaczenia (Dz.U. RP Nr 86, poz. 773), a dnia 22 sierpnia 1928 roku rozporządzenie w sprawie ustanowienia w miastach: Lublinie, Lwowie, Poznaniu i Wilnie sędziów śledczych do spraw wyjątkowego znaczenia (Dz.U. RP Nr 79, poz. 700). Na postawie pierwszego z wymienionych rozporządzeń, z 1927 roku, w Warszawie ustanowiono trzech sędziów śledczych do spraw wyjątkowego znaczenia (§ 1). Natomiast $\mathrm{w}$ miastach wymienionych w drugim rozporządzeniu, z $1928 \mathrm{roku}$, ustanowiono ich po jednym w każdym $\mathrm{z}$ wymienionych miast (§ 1). W Poznaniu na podstawie $\S 1$ rozporządzenia Ministra Sprawiedliwości z dnia 15 października 1935 roku w sprawie oznaczenia liczby sędziów śledczych do spraw wyjątkowego znaczenia w Sądzie Apelacyjnym w Poznaniu (Dz.U. RP Nr 80, poz. 496) podniesiono ich liczbę do dwóch, w 1938 roku zaś ich liczbę przy sądzie w Warszawie podniesiono do czterech a przy sądzie we Lwowie do dwóch ${ }^{21}$. W Sądzie Apelacyjnym w Krakowie sędziego śledczego do spraw wyjątkowego znaczenia powołano dopiero w 1934 roku. Został nim Marian Szromba ${ }^{22}$. Warto dodać, że w latach 1937-1939 funkcjonował również sędzia śledczy do spraw wyjątkowego znaczenia w Warszawie z siedzibą w Lodzi ${ }^{23}$. Natomiast co ciekawe, nigdy nie ustanowiono sędziego śledczego do spraw wyjątkowego znaczenia w Sądzie Apelacyjnym w Katowicach ${ }^{24}$.

Sędziów śledczych do spraw wyjątkowego znaczenia mianował Prezydent Rzeczypospolitej na wniosek Rady Ministrów, uchwalony z inicjatywy Ministra Sprawiedliwości. Kandydaci na to stanowisko musieli przynajmniej pięć lat zajmować stanowisko sędziowskie lub prokuratorskie (art. 2 rozporządzenia z 1927 roku). Projekt ustawy z 1924 roku był w tym względzie trochę bardziej precyzyjny, stanowiąc, że muszą to być osoby, które przynajmniej przez 3 lata zajmowały w sądach okręgowych wyższe stanowiska sędziowskie lub prokuratorskie ${ }^{25}$. Fakt, że pod względem uposażenia byli oni zrównani z sędziami sądu apelacyjnego ich siedziby, powodował, że raczej nie było kłopotu z chętnymi na to stanowisko w porównaniu do stanowisk sędziów śledczych innych sądów, które często były obsadzane dopiero co egzaminowanymi aplikantami sądowymi. Pod względem

21 Rozporządzenie Ministra Sprawiedliwości z dnia 13 czerwca 1938 roku w sprawie powiększenia liczby sędziów śledczych do spraw wyjątkowego znaczenia w sądach apelacyjnych we Lwowie i Warszawie (Dz.U. RP Nr 43, poz. 361, § 1).

${ }^{22}$ L. Krzyżanowski, Sędziowie w II Rzeczypospolitej. Okręgi apelacyjne: krakowski i katowicki, Katowice 2011, s. 161.

23 Potwierdzają to archiwalia Sądu Okręgowego w Łodzi z tego okresu.

24 L. Krzyżanowski, op. cit. Podobnie jak w Sądzie Apelacyjnym w Toruniu, który istniał do końca 1933 roku; por. T. Pietrykowski, Są Apelacyjny w Toruniu 1920-1933, Toruń 1934.

25 Sędziowie śledczy do spraw..., s. 1155. 
uposażenia sędziowie śledczy do spraw wyjątkowego znaczenia byli zaszeregowani do drugiej lub trzeciej grupy, co w 1938 roku wiązało się z 800 lub 575 zł miesięcznego wynagrodzenia.

Ustalenie pełnej listy sędziów śledczych do spraw wyjątkowego znaczenia czynnych w okresie międzywojennym nie jest możliwe. Udało mi się ich ustalić 25 (plus jeden, Jan Sehn, czynny dopiero po II wojnie światowej). Ich wykaz znajduje się w aneksie do artykułu. Pierwszych trzech sędziów śledczych do spraw wyjątkowego znaczenia powołano dnia 28 października 1927 roku. Zostali nimi dotychczasowi sędziowie śledczy zapasowi Sądu Okręgowego w Warszawie Jerzy Luxenburg ${ }^{26}$, Józef Skorzyński i Teodor Wituński, którzy zostali sędziami apelacyjnymi śledczymi Sądu Apelacyjnego w Warszawie. Najbardziej znanym w Polsce w okresie międzywojennym spośród sędziów śledczych do spraw wyjątkowego znaczenia, okrytym ponurą sławą, był Jan Demant, sędzia Sądu Apelacyjnego w Warszawie. Prowadził on dochodzenie w sprawie przywódców Centrolewu oskarżonych w sławnym procesie brzeskim w 1931 roku. Dla ścisłości należy dodać, że dochodzenie we wspomnianej sprawie prowadził on, będąc jeszcze sędzią śledczym Sądu Okręgowego w Warszawie, a sędzią śledczym do spraw wyjątkowego znaczenia został ustanowiony za zasługi w tym procesie ${ }^{27}$. Dane dotyczące sędziów śledczych do spraw wyjątkowego znaczenia są niekiedy niezbyt precyzyjne. Przykładowo, mimo że Józef Skorzyński, ustanowiony w 1927 roku sędzią śledczym do spraw wyjątkowego znaczenia po tym, jak powierzono mu utworzenie ,instytutu do badań na potrzeby wymiaru sprawiedliwości”, nie był już oficjalnie wymieniany wśród sędziów śledczych do spraw wyjątkowego znaczenia Sądu Apelacyjnego w Warszawie, to jednak wielokrotnie później był określany jako sędzia apelacyjny śledczy ${ }^{28}$. Sędziowie śledczy do spraw wyjątkowego znaczenia byli o wiele bardziej zależni od Ministra Sprawiedliwości niż pozostali sędziowie. Ustanawiał on ich bowiem, decydował o ich liczbie i prowadzonych

26 Bratanek Róży Luksemburg.

27 Ł. Kopytko, Nie tylko proces - socjalista Adam Pragier w tzw. sprawie brzeskiej, „Res Historica” 2011, nr 32, s. 80, przyp. 38; S. Hoc, Czy możliwa jest rehabilitacja skazanych w tzw. procesie brzeskim?, „Opolskie Studia Administracyjno-Prawne” 14, 2016, nr 3, s. 102. Prowadzący w tej sprawie postępowanie prokurator Czesław Michałowski konsultował się także z sędzią śledczym do spraw wyjątkowego znaczenia Władysławem Chmielarzem - Czy wytocza proces?, „Gazeta Wągrowiecka” 10, 1930, nr 183, s. 1. W rzeczywistości W. Chmielarz podobnie jak J. Demant był sędzią śledczym Sądu Okręgowego w Warszawie.

28 Podobnie w literaturze podaje się, że takim sędzią był również Mieczysław Kleinert; por. J. Puchalski, Instytut Naukowego Badania Komunizmu w Warszawie (1930-1939): program, organizacja, zbiory, prace księgoznawcze, [w:] Bibliologia polityczna, red. D. Kuźmina, Warszawa 2011, s. 225. W rzeczywistości był on sędzią śledczym Sądu Okręgowego w Warszawie dla spraw specjalnie przydzielonych i politycznych, być może dlatego zaliczano go do sędziów śledczych do spraw wyjątkowego znaczenia - Kalendarz... na rok 1934, s. 161. Prowadził on między innymi sprawę przeciwko Stefanii Sempołowskiej - Pani Stefania Sempołowska. Proces „,Sygnałów”, „Robotnik” 40, 1938, nr 95, s. 3. 
przez nich sprawach. Praktycznie pozostawali oni w jego dyspozycji, mógł on między innymi ich przenieść, jak na przykład Stanisława Korusiewicza do Warszawy (26 kwietnia 1938 roku), a Franciszka Wójcickiego do Krakowa (28 kwietnia 1938 roku). Być może te dwie nominacje z sobą się wiążą; Korusiewicz wcześniej był bowiem sędzią Sądu Okręgowego w Krakowie, a Wójcicki — Sądu Okręgowego w Warszawie, zamienili się oni zatem miejscami.

Instytucja sędziów śledczych do spraw wyjątkowego znaczenia - wprawdzie w o wiele mniejszym zakresie - funkcjonowała także po II wojnie światowej. W okresie tym czynnych było dwóch znanych sędziów śledczych do spraw wyjątkowego znaczenia. Byli to Józef Skorzyński i Jan Sehn, obydwaj związani z Instytutem Ekspertyz Sądowych (powstałym w 1929 roku). Skorzyński był jego organizatorem i pierwszym dyrektorem w okresie międzywojennym, a Sehn — dyrektorem od 1949 roku. Łączyła ich także działalność w Głównej Komisji Badania Zbrodni Niemieckich w Polsce, do której zostali oddelegowani - Skorzyński formalnie był sędzią śledczym do spraw wyjątkowego znaczenia powołanym do pełnienia czynności w Ministerstwie Sprawiedliwości, a Sehn sądu w Krakowie 29 .

Powołanie sędziów śledczych do spraw wyjątkowego znaczenia w okresie międzywojennym było poddawane krytyce ze względu na niewprowadzenie definicji spraw wyjątkowego znaczenia oraz uznaniowość w podziale spraw na wyjątkowe oraz takie, do których przydzielano zwykłych sędziów śledczych, podając w ten sposób w wątpliwość ich kompetencje względem sędziów śledczych do spraw wyjątkowego znaczenia ${ }^{30}$. Nadawanie w prawie niektórym instytucjom statusu „wyjątkowości” z reguły istotnie budzi podejrzenie o ich upolitycznienie. Podobnie było z instytucją sędziów śledczych do spraw wyjątkowego znaczenia. O ile początkowo u podstaw ich ustanowienia leżały względy natury merytorycznej (wspomniana znajomość międzydzielnicowego prawa), o tyle później zwłaszcza po wydaniu w 1932 roku kodeksu karnego — były to już rzeczywiście częściowo względy natury politycznej (sprawy sędziów Demanta ${ }^{31}$ i Skorzyńskiego). O wzroście znaczenia sędziów śledczych do spraw wyjątkowego znaczenia w Polsce po 1927 roku, po pierwszym okresie ich rozwoju, świadczy z czasem ich ustanowienie przy prawie wszystkich sądach apelacyjnych w Polsce - z wyjątkiem sądu w Katowicach i krótko istniejącego Sądu Apelacyjnego w Toruniu i powiększanie ich liczby przy poszczególnych sądach. Z czasem zaczęto wyznaczać im także siedzibę w miastach, które nie były siedzibą sądu apelacyjnego. Tak stało się w 1938 roku odnośnie do Łodzi i Równego — miast, w których nie

29 M. Kłusek, Dziennik Hansa Franka jako źródło historyczne do badań nad okupacją niemiecka podczas II wojny światowej, „Krakowskie Studia Małopolskie” 2014, nr 19, s. 91.

30 A. Węklar, op. cit.

31 Określano, że „wyróżniał się zoologiczną nienawiścią do komunizmu” — B. Dymek, Białostocki okręg Niezależnej Partii Chłopskiej, „Rocznik Białostocki” 12, 1974, s. 336, przyp. 42. 
było sądów apelacyjnych. Swoją siedzibę w Łodzi miał sędzia śledczy do spraw wyjątkowego znaczenia Sądu Apelacyjnego w Warszawie, którym zaledwie trzy tygodnie wcześniej został mianowany Stanisław Korusiewicz ${ }^{32}$. Natomiast sędzią w Równem był Piotr Obst, który także formalnie ledwo tydzień wcześniej został sędzią śledczym do spraw wyjątkowego znaczenia Sądu Apelacyjnego w Lublinie. W przypadku Piotra Obsta jedyną istotną zmianą był jego awans na sędziego śledczego do spraw wyjątkowego znaczenia. W pozostałym zakresie w odniesieniu do niego nic w rzeczywistości się nie zmieniło, przed awansem na sędziego śledczego do spraw wyjątkowego znaczenia Sądu Apelacyjnego w Lublinie był on bowiem sędzią okręgowym śledczym w Równym, gdzie ostatecznie wyznaczono mu siedzibę jako sędziemu śledczemu do spraw wyjątkowego znaczenia ${ }^{33}$. W obydwu tych miejscowościach (to jest w Łodzi i Równem) była w owym czasie bardzo niespokojna sytuacja wewnętrzna związana z ekscesami antyżydowskimi.

Sędziowie śledczy do spraw wyjątkowego znaczenia formalnie zakończyli swoją działalność dnia 1 lipca 1949 roku, kiedy to rozporządzenie o sędziach śledczych do spraw wyjątkowego z znaczenia z 1927 roku utraciło moc obowiązującą. Nastąpiło to na podstawie art. 2 pkt 1 ustawy z dnia 27 kwietnia 1949 roku o zmianie prawa o ustroju sądów powszechnych (Dz.U. Nr 32, poz. 237). W wyniku reform postępowania karnego z 1949 roku najbardziej radykalne zmiany dotknęły postępowanie przygotowawcze. Oprócz wprowadzenia jednolitej jego formy w postaci śledztwa i likwidacji instytucji sędziów śledczych postępowanie przygotowawcze podporządkowano prokuratorowi. Jego nadzór nad nim w praktyce był jednakże fikcją, ponieważ szerokich upoważnień do prowadzenia śledztw we wszystkich ważniejszych sprawach, zwłaszcza o aspekcie politycznym, udzielono funkcjonariuszom Ministerstwa Bezpieczeństwa Publicznego, którzy w tym zakresie uzyskali przewagę nad organami prokuratury ${ }^{34}$.

32 Dziennik Urzędowy Ministerstwa Sprawiedliwości 1938, nr 5, s. 81; nr 6, s. 92; Kalendarz Informator Sądowy na rok 1939, oprac. J. Kirkiczenko, M. Kraczkiewicz, M. Rudzisz, Warszawa [b.d.], s. 219.

33 Dziennik Urzędowy Ministerstwa Sprawiedliwości 1938, nr 5, s. 81; nr 6, s. 92.

34 J. Koredczuk, Ksztaltowanie się modelu polskiego procesu karnego w latach 1918-1955, [w:] System Prawa Karnego Procesowego, red. P. Hofmański, t. 1, cz. 1. Zagadnienia ogólne, red. P. Hofmański, Warszawa 2013, s. 357-358. 


\section{Aneks I. Wykaz sędziów śledczych do spraw wyjątkowego znaczenia}

\begin{tabular}{|c|c|c|c|c|}
\hline Lp. & Imię i nazwisko & $\begin{array}{c}\text { Sąd } \\
\text { Apelacyjny }\end{array}$ & $\begin{array}{c}\text { Data } \\
\text { powołania }\end{array}$ & Prowadzone sprawy \\
\hline 1. & Stanisław Bohusz ${ }^{1}$ & Poznań & 3 XII 1928 & \\
\hline 2. & Antoni Borejko ${ }^{2}$ & Wilno & $16 \times 1928$ & \\
\hline 3. & Kazimierz Bury ${ }^{3}$ & Lublin & & \\
\hline 4. & Stefan Cisło ${ }^{4}$ & Lwów & 7 XI 1938 & \\
\hline 5. & Jan Demant & Warszawa & & $\begin{array}{l}\text { 1. Proces brzeski }{ }^{5} \\
\text { 2. Proces przeciwko centralnemu } \\
\text { komitetowi K. P. Z. U. }{ }^{6} \\
\text { 3. Tak zwany proces łucki }{ }^{7} \\
\text { 4. Sprawa Zakładów Żyrardowskich }{ }^{8}\end{array}$ \\
\hline 6. & $\begin{array}{l}\text { Kazimierz Oswald } \\
\text { Januszewski }\end{array}$ & Lwów & 4 VII 1930 & Sprawa członków prezydium $\mathrm{UNDO}^{9}$. \\
\hline 7. & $\begin{array}{l}\text { Stanisław } \\
\text { Korusiewicz }\end{array}$ & $\begin{array}{l}\text { Kraków }^{10} \\
\text { Warszawa }^{11} \\
\text { Łódź }^{12}\end{array}$ & $\begin{array}{l}1936 \\
26 \text { IV } 1938 \\
16 \text { V } 1938 \\
\end{array}$ & Afera Wandy Parylewiczowej ${ }^{13}$. \\
\hline
\end{tabular}

1 „Ruch służbowy. Dodatek do Dziennika Urzędowego Ministerstwa Sprawiedliwości” 1929, nr 3, s. 31 .

2 Dziennik Urzędowy Ministerstwa Sprawiedliwości 1928, nr 23, s. 446.

3 Na dzień 1 stycznia 1939 roku było ich 2 na 22 sędziów tego sądu - Historia Sądu, www. lublin.sa.gov.pl/67.informacje-dodatkowe.html (dostęp: 31 marca 2020).

${ }^{4}$ Dziennik Urzędowy Ministerstwa Sprawiedliwości 1938, nr 12, s. 139.

5 Ł. Kopytko, op. cit.

${ }^{6}$ Aresztowanie 30 komunistów z K. P. Z. U. Sędzia Demant prowadzi śledztwo we Lwowie, „Ziemia Lubelska” 27, 1931, nr 169, s. 1.

7 Proces członków Komunistycznej Partii Zachodniej Ukrainy w 1934 roku; Ł. Bojko, Komunistyczna Partia zachodniej Ukrainy i tzw. proces tucki, „Studia nad Autorytaryzmem i Totalitaryzmem" 38, 2016, nr 3, s. 107.

8 E. Rembikowska, Zloty interes, „Szkoła Nawigatorów” 2016, nr 11, ewa-rembikowska.szkolanawigatorow.pl/zloty-interes; Rząd polski nie przyjąt do wiadomości francuskiego wystapienia, „Dziennik Ostrowski” 2, 1934, nr 189, s. 2.

9 Aresztowanie członków prezydjum UNDO, „Gazeta Lwowska” 120, 1930, nr 253, s. 3.

${ }^{10}$ L. Krzyżanowski, op. cit.

11 Dziennik Urzędowy Ministerstwa Sprawiedliwości 1938, nr 5, s. 81.

12 Dziennik Urzędowy Ministerstwa Sprawiedliwości 1938, nr 6, s. 92; Kalendarz... na rok 1939, s. 219.

13 Afera Wandy Parylewiczowej, „Gazeta Lwowska” 129, 1936, nr 115, s. 3; Jak toczy się śledztwo $w$ aferze Parylewiczowej, „Gazeta Wągrowiecka” 16, 1936, nr 158, s. 2. Była ona żoną byłego prezesa Sądu Apelacyjnego w Krakowie oraz siostrą zamordowanego ministra spraw wewnętrznych Bronisława Pierackiego. 


\begin{tabular}{|c|c|c|c|c|}
\hline 8. & Aleksander Lindert & Lwów & 1933 & $\begin{array}{l}\text { 1. Sprawa Borysa Rybakowa }{ }^{14} \\
\text { 2. Afera w Teatrze Miejskim we } \\
\text { Lwowie }^{15}\end{array}$ \\
\hline 9. & $\begin{array}{l}\text { Kazimierz } \\
\text { Kwiatkowski }^{16}\end{array}$ & Wilno & 1934 & \\
\hline 10. & Jerzy Luxenburg ${ }^{17}$ & Warszawa & $28 \times 1927$ & $\begin{array}{l}\text { 1. Afera podsłuchowa Jana Seinfelda }{ }^{18} \\
\text { 2. Zabójstwo podkomisarza straży } \\
\text { granicznej Liskiewicza }^{19}\end{array}$ \\
\hline 11. & $\begin{array}{l}\text { Maksymilian } \\
\text { Ładyżyński }^{20}\end{array}$ & Poznań & & \\
\hline 12. & $\begin{array}{l}\text { Hubert } \\
\text { Myszkorowski }^{21}\end{array}$ & Poznań & $10 \times 1936$ & \\
\hline 13. & $\begin{array}{l}\text { Andrzej } \\
\text { Nowakowski }\end{array}$ & Poznań & & \\
\hline 14. & Piotr Obst & $\begin{array}{l}\text { Lublin }^{22} \\
\text { Równe } \\
\end{array}$ & $\begin{array}{l}28 \text { IV } 1938 \\
5 \text { V } 1938\end{array}$ & \\
\hline 15. & $\begin{array}{l}\text { Edward Wilhelm } \\
\text { Ojak }^{24}\end{array}$ & Lwów & $1 \times 1928$ & \\
\hline 16. & Lucjan Podwiński $^{25}$ & Lublin & 3 XII 1928 & \\
\hline 17. & Jan $\operatorname{Sehn}^{26}$ & Kraków & VIII 1947 & $\begin{array}{l}\text { Przygotowanie aktu oskarżenia Rudolfa } \\
\text { Hössa }\end{array}$ \\
\hline
\end{tabular}

14 Sensacyjny zwrot w aferach magistrackich we Lwowie, „Ilustrowany Kuryer Codzienny” 24, 1933, nr 274, s. 15.

15 Sprawa dochodzeń sądowych w teatrach lwowskich, „Kurjer Powszechny” 7, 1934, nr $82 \mathrm{ABC}$, s. 5.

16 Kalendarz... na rok 1934, s. 264.

17 Dziennik Urzędowy Ministerstwa Sprawiedliwości 1928, nr 1, s. 21.

18 Seinfeld na wolności, „Gazeta Lwowska” 120, 1930, nr 49, s. 1; W sprawie afery Seinfelda. Przestuchanie dziennikarza żydowskiego, „Express Lubelski” 8, 1930, s. 2.

19 Szpiegowska prowokacja, „Hasło Łódzkie” 4, 1930, nr 145, s. 1.

20 Dziennik Urzędowy Ministerstwa Sprawiedliwości 1937, nr 8, s. 100.

21 Dziennik Urzędowy Ministerstwa Sprawiedliwości 1936, nr 16, s. 155; Nominacje sędziów i prokuratorów, „Gazeta Lwowska” 129, 1936, nr 238, s. 2. Zastąpił Zygmunta Wolskiego.

22 Dziennik Urzędowy Ministerstwa Sprawiedliwości 1938, nr 5, s. 81. Na dzień 1 stycznia 1939 roku było ich 2 na 22 sędziów tego sądu — Historia Sądu, www.lublin.sa.gov.pl/67.informacje-dodatkowe.html (dostęp: 31 marca 2020).

23 Dziennik Urzędowy Ministerstwa Sprawiedliwości 1938, nr 6, s. 92.

24 Dziennik Urzędowy Ministerstwa Sprawiedliwości 1928, nr 23, s. 446.

25 A. Bereza, Ścieżki kariery prawniczej sędziów okręgowych w Zamościu w niepodległym Państwie Polskim (do 31 grudnia 1928 r.), „Z Dziejów Prawa” 12, 2019, s. 484; „Ruch służbowy. Dodatek do Dziennika Urzędowego Ministra Sprawiedliwości” 1929, nr 3, s. 31.

${ }^{26}$ https://www.ies.gov.pl/index.php/pl/o-onstytucje/historia-1/104 (dostęp: 2 kwietnia 2020). 


\begin{tabular}{|c|c|c|c|c|}
\hline 18. & Julian Sekita ${ }^{27}$ & Wilno & $\begin{array}{l}29 \mathrm{VII} \\
1937\end{array}$ & \\
\hline 19. & Witold Skinder $^{28}$ & Wilno & & \\
\hline 20. & Józef Skorzyński ${ }^{29}$ & Warszawa & $28 \times 1927$ & $\begin{array}{l}\text { 1. Zamach na Marszałka Piłsudskiego }{ }^{30} \\
\text { 2. Szajka fałszerzy pieniędzy Zelmana } \\
\text { vel Salomona Jeleniewa }{ }^{31} \\
\text { 3. Zabójstwo Emiliana } \\
\text { Czechowskiego } \\
\text { 4. Zabójstwo Tadeusza Hołówki }{ }^{33} \\
\text { 5. Zamach na płka Koca } \\
\text { 6. Sprawa Jürgena Stroopa } \\
\text { 35 }\end{array}$ \\
\hline 21. & Marian Szromba ${ }^{36}$ & Kraków & 1934 & \\
\hline 22. & $\begin{array}{l}\text { Stanisław } \\
\text { Tomaszunas }^{37}\end{array}$ & Warszawa & 13 I 1939 & \\
\hline 23. & $\begin{array}{l}\text { Kazimierz } \\
\text { Waligórski }\end{array}$ & Lwów & 1935 & $\begin{array}{l}\text { 1. Sprawa nadużyć w Sądzie Grodzkim } \\
\text { w Jarosławiu }{ }^{38} \\
\text { 2. Sprawa afery w starostwie } \\
\text { powiatowym we Lwowie } \\
\text { 3. Sprawa nadużyć w Miejskiej } \\
\text { Komunalnej Kasie Oszczędności } \\
\text { w Stanisławowie }\end{array}$ \\
\hline
\end{tabular}

27 Zastąpił on Witolda Skindera — Dziennik Urzędowy Ministerstwa Sprawiedliwości 1937, nr 8, s. 101.

28 Dziennik Urzędowy Ministerstwa Sprawiedliwości 1937, nr 8, s. 101. Zastąpił go Julian Sekita.

29 Dziennik Urzędowy Ministerstwa Sprawiedliwości 1928, nr 1, s. 21.

30 Oświadczenie sędziego śledczego w sprawie planowanego zamachu na Marszałka Pitsudskiego, „Gazeta Lwowska” 120, 1930, nr 241, s. 1.

31 Białostockie szczury, „Tajny Detektyw” 2, 1932, nr 49; retropress.p/tajny-detektyw/białostockie-szczury/ (dostęp: 2 kwietnia 2020).

32 Emilian Czechowski był komisarzem policji we Lwowie, który kierował referatem spraw ukraińskich w komendzie wojewódzkiej. Prowadził między innymi śledztwo w sprawie zabójstwa Tadeusza Hołówki. Został zabity 5 maja 1932 roku; Ujęcie mordercy, „Kurier Warszawski” 102, 1932, nr 124, s. 18.

33 Echa zamordowania ś.p. Hołówki. We wrześniu odbędzie się proces w Samborze, „ABC” 8-C, 1933, nr 233, s. 4.

34 W 1937 roku - Po wybuchu bomby koło domu ptka Koca, „Kurier Poznański” 32, 1937, nr 325 , s. 2.

35 T. Stempowski, Raport Stroopa - fakty i domysty, fototekst.pl/raport-stroopa-fakty-i-domysly/ (dostęp: 3 kwietnia 2020).

36 L. Krzyżanowski, op. cit.; Kalendarz... na rok 1934, s. 67.

37 Dziennik Urzędowy Ministerstwa Sprawiedliwości 1939, nr 3, s. 50.

38 Dochodzenie w sprawie nadużyć w Sadzie grodzkim w Jarosławiu, „Gazeta Lwowska” 125, 1935, nr 126, s. 2.

39 Afera inwalidzka, „Gazeta Lwowska” 129, 1936, nr 279, s. 3.

40 Dochodzenia w sprawie nadużyć w Stanistawowie, „Gazeta Lwowska” 130, 1937, nr 13, s. 3. 


\begin{tabular}{|l|l|l|l|l|}
\hline 24. & Teodor Wituński & Warszawa & 28 X 1927 & $\begin{array}{l}\text { 1. Afera fałszerstw paszportowych } \\
\text { 2. Zabójstwo ministra Bronisława } \\
\text { Pierackiego } 43\end{array}$ \\
\hline 25. & Zygmunt Wolski ${ }^{44}$ & Poznań & 1934 & \\
\hline 26. & $\begin{array}{l}\text { Franciszek } \\
\text { Wójcicki }^{45}\end{array}$ & Kraków & 28 IV 1938 & \\
\hline
\end{tabular}

\section{Aneks II. Obsada sądów apelacyjnych sędziami śledczymi do spraw wyjątkowego znaczenia}

\begin{tabular}{|l|l|l|l|l|l|}
\hline \multicolumn{1}{|c|}{ Kraków } & \multicolumn{1}{c|}{ Lublin } & \multicolumn{1}{c|}{ Lwów } & \multicolumn{1}{c|}{ Poznań } & \multicolumn{1}{c|}{ Warszawa } & \multicolumn{1}{c|}{ Wilno } \\
\hline Marian & Lucjan Pod- & Edward Wil- & Stanisław & Jerzy Luxen- & Antoni Bo- \\
Szromba & wiński 3 XII & helm Ojak & Bohusz 3 XII & burg 26 X & rejko 16 X \\
1934- & 1928- & 1 X 1928-23 & 1928- & 1927- & 1928-1 XI \\
Stanisław & Kazimierz & XII 1929 & Zygmunt & Józef Sko- & 1932 \\
Korusiewicz & Bury 1934- & Kazimierz & Wolski 1934- & rzyński 28 X & Witold Skin- \\
1936-25 IV & Piotr Obst 28 & Oswald Janu- & 10 X 1936 & 1927- & der 1933-29 \\
1938 & IV 1938-4 V & szewski 4 VII & Hubert Mysz- & Teodor Wi- & VII 1937 \\
Franciszek & 1938 & 1930- & korowski 10 & tuński 28 X & Julian Sekita \\
Wójcicki 28 & (Równe 5 V & Aleksander & X 1936- & 1927-29 IX & 29 VII 1937- \\
IV 1938- & $1938-)$ & Lindert 1933- & Maksymilian & 1938 & Kazimierz \\
Jan Sehn VIII & & Kazimierz & Ladyżyński & Jan Demant & Kwiatkowski \\
1947- & & Waligórski & 29 VII 1937- & 1931-31 & 1934- \\
& & 1935- & Andrzej & I 1939 & \\
& & Stefan Cisło & Nowakowski & Stanisław Ko- & \\
& & 7 IX 1938- & & rusiewicz 26 & \\
& & & & IV 1938-15 & \\
& & & & V 1938 & \\
& & & & (Lódź 16 V & \\
& & & & 1938-) & \\
& & & & Stanisław & \\
& & & & Tomaszunas & \\
& & & & & \\
& & & & &
\end{tabular}

41 Dziennik Urzędowy Ministerstwa Sprawiedliwości 1928, nr 1, s. 21.

42 Wicekonsul St. Zjed. $w$ Warszawie wmieszany $w$ afere fatszerstw paszportowych, „Gazeta Lwowska" 120, 1930, nr 49, s. 3.

43 A. Garlicki, Piękne lata dwudzieste, Warszawa 2008.

${ }^{4}$ Kalendarz... na rok 1934, s. 124. Zastąpił go Hubert Myszkorowski.

45 Dziennik Urzędowy Ministerstwa Sprawiedliwości 1938, nr 5, s. 81; L. Krzyżanowski, op. cit. Zastąpił Stanisława Korusiewicza. 


\section{Bibliografia}

\section{Akty prawne}

Dekret Prezydenta Rzeczypospolitej z dnia 21 października 1944 roku o zmianie niektórych przepisów prawa o ustroju sądów powszechnych (Dz.U. RP na Uchodźstwie Nr 12, cz. I, poz. 23).

Rozporządzenie Ministra Sprawiedliwości z dnia 27 września 1927 roku w sprawie ustanowienia w m. st. Warszawie sędziów śledczych do spraw wyjątkowego znaczenia (Dz.U. RP Nr 86, poz. 773 ).

Rozporządzenie Ministra Sprawiedliwości z dnia 22 sierpnia 1928 roku w sprawie ustanowienia w miastach: Lublinie, Lwowie, Poznaniu i Wilnie sędziów śledczych do spraw wyjątkowego znaczenia (Dz.U. RP Nr 79, poz. 700).

Rozporządzenie Ministra Sprawiedliwości z dnia 15 października 1935 roku w sprawie oznaczenia liczby sędziów śledczych do spraw wyjątkowego znaczenia w Sądzie Apelacyjnym w Poznaniu (Dz.U. RP Nr 80, poz. 496).

Rozporządzenie Ministra Sprawiedliwości z dnia 13 czerwca 1938 roku w sprawie powiększenia liczby sędziów śledczych do spraw wyjątkowego znaczenia w sądach apelacyjnych we Lwowie i Warszawie (Dz.U. RP Nr 43, poz. 361).

Rozporządzenie Prezydenta Rzeczypospolitej z dnia 22 kwietnia 1927 roku o postępowaniu sądowym w razie naruszenia postanowień art. 22 Konstytucji (Dz.U. RP. Nr 41, poz. 368).

Rozporządzenie Prezydenta Rzeczypospolitej z dnia 15 lipca 1927 roku o sędziach śledczych do spraw wyjątkowego znaczenia (Dz.U. RP Nr 69, poz. 611).

Rozporządzenia Prezydenta Rzeczypospolitej z dnia 6 lutego 1928 roku Prawo o ustroju sądów powszechnych (Dz.U. RP Nr 12, poz. 93).

Rozporządzenie Prezydenta Rzeczypospolitej z dnia 19 marca 1928 roku Kodeks postępowania karnego (Dz.U. RP Nr 33, poz. 313).

Rozporządzenie Prezydenta Rzeczypospolitej z dnia 19 marca 1928 roku Przepisy wprowadzające kodeks postępowania karnego (Dz.U. RP Nr 33, poz. 314).

Rozporządzenie Prezydenta Rzeczypospolitej z dnia 24 października 1934 roku o niektórych przestępstwach przeciwko bezpieczeństwu Państwa (Dz.U. RP Nr 94, poz. 851).

Ustawa z dnia 15 lutego 1921 roku w przedmiocie zmian w ustawodawstwie karnem, obowiązującem w b. zaborze rosyjskim (Dz.U. RP Nr 30, poz. 169).

Ustawa z dnia 23 kwietnia 1923 roku o Trybunale Stanu (Dz.U. RP Nr 59, poz. 415).

Ustawa z dnia 14 lipca 1936 roku o Trybunale Stanu (Dz.U. RP Nr 56, poz. 403).

Ustawa z dnia 27 kwietnia 1949 roku o zmianie prawa o ustroju sądów powszechnych (Dz.U. Nr 32, poz. 237).

\section{Źródła drukowane}

Dziennik Urzędowy Ministerstwa Sprawiedliwości 1928, nr 1 i 23.

Dziennik Urzędowy Ministerstwa Sprawiedliwości 1936, nr 16.

Dziennik Urzędowy Ministerstwa Sprawiedliwości 1937, nr 8.

Dziennik Urzędowy Ministerstwa Sprawiedliwości 1938, nr 5, 6 i 12.

Dziennik Urzędowy Ministerstwa Sprawiedliwości 1939, nr 3.

Kalendarz Informator Sadowy na rok 1934, oprac. J. Kirkiczenko, M. Kraczkiewicz, K. Rudzisz, Warszawa [b.r.].

Kalendarz Informator Sadowy na rok 1939, oprac. J. Kirkiczenko, M. Kraczkiewicz, M. Rudzisz, Warszawa [b.d.].

Prawo 330, 2020

(C) for this edition by CNS 
Okólnik Nr. 1422/I. U/28 dotyczący prawa o ustroju sądów powszechnych, Dziennik Urzędowy Ministerstwa Sprawiedliwości 1928, nr 19.

„Ruch służbowy. Dodatek do Dziennika Urzędowego Ministerstwa Sprawiedliwości” 1929, nr 3.

Zbiór Wyroków Najwyższego Trybunału Administracyjnego 12, 1934, red. K. Bernaczyk, W. Borkowski, A. Dubieński, Z. Smolka, Warszawa 1935.

\section{Literatura}

Afera inwalidzka, „Gazeta Lwowska” 129, 1936, nr 279.

Afera Wandy Parylewiczowej, „Gazeta Lwowska” 129, 1936, nr 115.

Aresztowanie 30 komunistów z K. P. Z. U. Sędzia Demant prowadzi śledztwo we Lwowie, „Ziemia Lubelska" 27, 1931, nr 169.

Aresztowanie członków prezydjum UNDO, „Gazeta Lwowska” 120, 1930, nr 253.

Bereza A., Ścieżki kariery prawniczej sędziów okręgowych w Zamościu w niepodległym Państwie Polskim (do 31 grudnia 1928 r.), „Z Dziejów Prawa” 12, 2019.

Bojko Ł., Komunistyczna Partia Zachodniej Ukrainy i tzw. proces tucki, „Studia nad Autorytaryzmem i Totalitaryzmem" 38, 2016, nr 3.

Czerwiński A., Ustrój sądów powszechnych wedle rozporządzenia Prezydenta Rzeczypospolitej $z$ dnia 6 lutego 1928 r. Dz. Ust. Nr. 12, poz. 93, Lwów 1928.

Czy wytocza proces?, „Gazeta Wągrowiecka” 10, 1930, nr 183.

Dochodzenia w sprawie nadużyć w Stanisławowie, „Gazeta Lwowska” 130, 1937, nr 13.

Dochodzenie w sprawie nadużý w Sądzie grodzkim w Jarostawiu, „Gazeta Lwowska” 125, 1935, nr 126.

Dymek B., Białostocki okręg Niezależnej Partii Chłopskiej, „Rocznik Białostocki” 12, 1974.

Echa zamordowania ś.p. Hołówki. We wrześniu odbędzie się proces w Samborze, „ABC” 8-C, 1933, nr 233.

Eichstaedt K., Instytucja sędziego śledczego w okresie międzywojennym, „Studia z Dziejów Państwa i Prawa Polskiego" 17, 2014.

Garlicki A., Piękne lata dwudzieste, Warszawa 2008.

Gumiński J., Zakres działania Sądu najwyższego w świetle nowych przepisów, „Głos Sądownictwa" 1, 1929, nr 1.

Hoc S., Czy możliwa jest rehabilitacja skazanych w tzw. procesie brzeskim?, „Opolskie Studia Administracyjno-Prawne" 14, 2016, nr 3.

Jak toczy się śledztwo w aferze Parylewiczowej, „Gazeta Wągrowiecka” 16, 1936, nr 158.

Kłusek M., Dziennik Hansa Franka jako źródło historyczne do badań nad okupacja niemiecka podczas II wojny światowej, „Krakowskie Studia Małopolskie” 2014, nr 19.

Kopytko Ł., Nie tylko proces — socjalista Adam Pragier w tzw. sprawie brzeskiej, „Res Historica" 2011, nr 32.

Koredczuk J., Ewolucja modelu postepowania przygotowawczego, [w:] System Prawa Karnego Procesowego, red. P. Hofmański, t. 10. Postępowanie przygotowawcze, red. R.A. Stefański, Warszawa 2016.

Koredczuk J., Kształtowanie się modelu polskiego procesu karnego w latach 1918-1955, [w:] System Prawa Karnego Procesowego, red. P. Hofmański, t. 1, cz. 1. Zagadnienia ogólne, red. P. Hofmański, Warszawa 2013.

Koredczuk J., Wpływ francuskiego kodeksu postępowania karnego z 1808 roku na polski kodeks postępowania karnego z 1928 roku, [w:] Ze studiów nad tradycja prawa, red. E. Kozerska, P. Sadowski, A. Szymański, Warszawa 2012.

Koredczuk J., Wplyw nurtu socjologicznego na ksztalt polskiego prawa karnego procesowego w okresie międzywojennym (Les classiques modernes), Wrocław 2007.

Prawo 330, 2020

(C) for this edition by CNS 
Krzyżanowski L., Sędziowie w II Rzeczypospolitej. Okręgi apelacyjne: krakowski i katowicki, Katowice 2011.

Materniak-Pawłowska M., Instytucja sędziego śledczego w okresie międzywojennym, „Czasopismo Prawno-Historyczne" 65, 2013, z. 1.

Mogilnicki A., Śledztwo i akt oskarżenia wedtug k. p. k. i projektu, „Gazeta Sądowa Warszawska” $58,1930, \mathrm{nr} 2$.

Nestorowicz W., Stanowisko sędziego śledczego u nas i na zachodzie, „Głos Sądownictwa” 4, 1932, nr 3-4.

Nominacje sędziów i prokuratorów, „Gazeta Lwowska” 129, 1936, nr 238.

Oświadczenie sędziego śledczego w sprawie planowanego zamachu na Marszałka Pitsudskiego, „Gazeta Lwowska” 120, 1930, nr 241.

Pani Stefania Sempołowska. Proces ,,Sygnatów”, „Robotnik” 40, 1938, nr 95.

Pietrykowski T., Sąd Apelacyjny w Toruniu 1920-1933, Toruń 1934.

Po wybuchu bomby koło domu płka Koca, „Kurier Poznański” 32, 1937, nr 325.

Puchalski J., Instytut Naukowego Badania Komunizmu w Warszawie (1930-1939): program, organizacja, zbiory, prace księgoznawcze, [w:] Bibliologia polityczna, red. D. Kuźmina, Warszawa 2011.

Rząd polski nie przyjąt do wiadomości francuskiego wystapienia, „Dziennik Ostrowski” 2, 1934, nr 189.

Sandecki P., Adwokat profesor Zdzisław Papierkowski (1903-1980) - w 110. rocznice urodzin, „Palestra” 58, 2013, nr 3-4.

Seinfeld na wolności, „Gazeta Lwowska” 120, 1930, nr 49.

Sensacyjny zwrot w aferach magistrackich we Lwowie, „Ilustrowany Kuryer Codzienny” 24, 1933, nr 274.

Sędziowie śledczy do spraw wyjątkowego znaczenia, „Palestra” 2, 1925, nr 12.

Sprawa dochodzeń sądowych w teatrach lwowskich, „Kurjer Powszechny” 7, 1934, nr 82ABC.

Szpiegowska prowokacja, „Hasło Łódzkie” 4, 1930, nr 145.

Śliwiński S., Polski proces karny przed sądem powszechnym. Zasady ogólne, Warszawa 1948.

Ujęcie mordercy, „Kurier Warszawski” 102, 1932, nr 124.

W sprawie afery Seinfelda. Przestuchanie dziennikarza żydowskiego, „Express Lubelski” 8, 1930.

Węklar A., Instytucja sędziego śledczego do spraw postępowania przygotowawczego na tle uwarunkowań polskiego systemu prawnego — rozważania de lege ferenda, Warszawa 2019.

Wicekonsul St. Zjed. $w$ Warszawie wmieszany $w$ afere fatszerstw paszportowych, „Gazeta Lwowska" 120, 1930, nr 49.

\section{Źródła internetowe}

Białostockie szczury, „Tajny Detektyw” 2, 1932, nr 49, retropress.p/tajny-detektyw/białostockie-szczury/.

Historia Sąu, www.lublin.sa.gov.pl/67.informacje-dodatkowe.html.

https://www.ies.gov.pl/index.php/pl/o-onstytucje/historia-1/104.

Projekt ustawy o sędziach śledczych do spraw wyjątkowego znaczenia, https://bs.sejm.gov.pl/exlibris/aleph/a22_1/apache_media/3JY2NQTTI2ISIHTL9A9JNBM9EIDRH7.pdf.

Rembikowska E., Złoty interes, „Szkoła Nawigatorów” 2016, nr 11, ewa-rembikowska.szkolanawigatorow.pl/zloty-interes.

Stempowski T., Raport Stroopa — fakty i domysty; fototekst.pl/raport-stroopa-fakty-i-domysly/. 


\title{
Investigating judges for matters of special importance in the Second Polish Republic
}

\author{
Summary
}

Investigating judges for matters of special importance, established in 1927, did not draw on the French model of investigating judges we found in the Code of the Criminal Procedure, but on the Russian model providing for judges for matters of special importance. They were judges in charge of proceedings in the most difficult, complicated, especially important cases beyond the competence of district investigating judges. With time they were also entrusted with political cases (e.g. of individuals accused in the Brest trials). The judges not only presided over proceedings of special importance, but also had a unique legal status. They were appointed at the Court of Appeal, but were subordinated to the Minister of Justice (Chief Prosecutor), who decided which cases would be entrusted to them, which made the institution not only unique but also political.

Keywords: Code of Criminal Procedure, Minister of Justice, Law on the Organisation of Common Courts, Court of Appeal, investigating judge, investigating judge for matters of special importance

\section{Ermittlungsrichter für Angelegenheiten von besonderer Bedeutung in der Zweiten Polnischen Republik}

\section{Zusammenfassung}

Die im Jahre 1927 bestellten Ermittlungsrichter [sędzia śledczy] für Angelegenheiten von besonderer Bedeutung, knüpften nicht an das französische Modell der Ermittlungsrichter an, mit dem wir in der Strafprozessordnung zu tun hatten, sondern an das russische Modell, das Richter für Angelegenheiten von besonderer Bedeutung vorsah. Es waren Richter, die schwierigste, äußerst komplizierte und besonders wichtige Verfahren führten, die über den Kompetenzbereich eines Bezirksermittlungsrichters hinausreichten. Mit der Zeit beauftragte man sie auch mit Sachen politischen Charakters (z.B. mit der Vertretung der im Brester Prozess angeklagten Personen). Die erwähnten Richter führten Sachen von besonderer Bedeutung und ihr Rechtstatus war auch ein besonderer. Obwohl sie beim Appellationsgericht [sad apelacyjny] bestellt waren, so oblagen sie sachlich dem Justizminister (Oberstaatsanwalt), der über die ihnen anzuvertrauenden Sachen entschied. Auf diese Weise wurde aus einer außergewöhnlichen Institution noch eine politische.

Schlüsselwörter: Strafprozessordnung, Justizminister, das Recht über die Verfassung ordentlicher Gerichte, Appellationsgericht, Ermittlungsrichter, Ermittlungsrichter für Ausnahmefälle 